\title{
OBSERVATIONS OF ISOLATED PINGUICULA POPULATIONS IN THE WESTERN USA
}

\author{
BARRY RICE • Center for Plant Diversity • University of California • Davis, California 95616 \\ - USA • barry@sarracenia.com \\ Arthur Yin・San Jose, California •USA・arthuryin@gmail.com \\ Gina E. Morimoto•San Jose, California •USA・gemorimoto@gmail.com
}

Keywords: Observations: Pinguicula macroceras, Pinguicula vulgaris, California, Oregon, Montana.

Abstract

A site for Pinguicula in California, far from previously studied sites, is investigated in detail for the first time. Comparisons between this population and other western USA populations of Pinguicula are made, which suggest that the plants at this site seem more allied with Pinguicula macroceras Link subsp. macroceras than Pinguicula macroceras subsp. nortensis J. Steiger \& J.H. Rondeau. Further investigation is suggested to confirm the identity of these plants.

\section{Introduction}

The status of the species Pinguicula macroceras Link is a source of considerable disagreement in North America. The main source of this disagreement is rooted in arguments about whether it is truly distinct from Pinguicula vulgaris L (Casper 1962; Schnell 2002). In this paper, we summarize the current situation, setting the stage for the presentation of new data.

For these two species, the geographic situation (Casper 1966; Schlauer 2002; Schnell 2002) can be described in the following terms. In the lower 48 states of the USA, one can find P. macroceras in the west (Washington, Idaho, Montana, Oregon, and California), while P. vulgaris occurs in the east (Minnesota, Wisconsin, Michigan, New York, and Maine). Looking northwards, the range for $P$. macroceras includes the Yukon, British Columbia, Alberta, and continues westwards through Alaska to Russia (Kamchatka Peninsula) and Japan. For P. vulgaris, the range includes all of the Canadian provinces except Nova Scotia, Prince Edward Island (and perhaps British Columbia); the range then continues eastward into the Old World. A potential range overlap and even hybridization zone for these two species may occur in Alaska, the Yukon, and possibly British Columbia.

Ecologically, P. macroceras is usually petrophilous (Steiger 1975), growing on wet outcrops of granite, serpentine, etc., and only occasionally in meadows. Meanwhile, $P$. vulgaris is more typically found in fens, dune swales, and sphagnous sites (Schnell 2002). However, it is possible that this is due more to suitable niche opportunities available in the two different geographic regions - $P$. vulgaris does occur on mossy rocks, wet seepages, and rock crevices in the upper Great Lakes region (Schnell 2002; Wells et al. 1999). Vegetatively, there are no reliable differences between the plants.

In flower, the primary difference is that the three lower corolla lobes (i.e., petals) are usually touching or overlapping in P. macroceras, while they are not touching in $P$. vulgaris (Casper 1962). This overlap is in part because the lower petals of $P$. macroceras are more broadly rounded (in this case, subobovate-oblong) vs. the petals of $P$. vulgaris, which are more bluntly rectangular (oblong). While this criterion sounds simple, it is harder to apply in the field than one might suspect from the illustrations in Casper (1962). For example, the standardized photographs of P. macroceras (Steiger 1978, Figures 13-14) show that the overlap is small indeed, and is often 
just a matter of the petals approaching overlap, but not quite achieving it. Meanwhile Steiger (1982, front cover) illustrates a $P$. macroceras plant of unspecified provenance in which the criterion of petals touching is easily observed. Although not documented in the literature, another character separating the flowers of these two species is that the corolla lobes of P. macroceras are further spread or reflexed, so the flower appears more open than the flowers of $P$. vulgaris (J. Steiger, pers. comm. 2008).

Another floral feature that Casper (1962) used is the degree of fusion of the two lower calyx lobes (i.e., sepals). They are split more along their length in $P$. macroceras than they are in $P$. vulgaris. Unfortunately, this character has caused some problems. First, Casper (1962) was inconsistent in his specification of the degree of calyx lobe fusion for P. vulgaris, indicating it to be "split up to $2 / 3$ of its length" in his key, but "grown together to $2 / 3$ of their length" in the body of his text. Since Casper later specifies that a distinguishing feature of P. macroceras is "its deeply separated lobes of the lower lip of the calyx", it is reasonable to conclude Casper's intentions were to say that the calyx lobes of $P$. vulgaris are fused for $2 / 3$ of their length. In his monographic treatment of $P$. vulgaris, Casper (1966) later wrote "labium inferum bilobum lobis usque ad 1/2-2/3 longitudinis connatis ovato-lanceolatis" (lower lip two-lobed, with lobes connate up to $1 / 2-2 / 3$ of their length, ovate-lanceolate), and for P. macroceras he noted "labium inferum bipartitum laciniis lanceolatis usque ad 1/2 longitudinis connatis divergentibus" (lower lip twolobed, with lanceolate lobes which are connate up to $1 / 2$ of their length and divergent), thus confirming his intentions. Nonetheless, we consider the calyx lobes to be a difficult criterion to use as there is an apparent lack of consensus in how one should measure this feature. Note that Casper's drawings of $P$. vulgaris calyces illustrate fusions of both 2/3 and 1/2 (Casper 1962, Figure 3, left and right respectively).

Flower sizes are also cited as useful demarcations between the two species. Casper (1962) presented graphs of the overall corolla length (including spur), and spur length alone. He found that although the curves overlapped considerably, there were separate peaks in both graphs. Casper (1962) also recognized a separate variety, P. macroceras var. microceras (Cham.) Casper, but eliminated this from his 1966 monograph. Likewise, we will not recognize this variety further. A summary of his ranges for corolla and spur length are given in our Table 1.

The capsules of both P. macroceras and P. vulgaris are both noted by Casper (1966) as being ovoid. A more complete description of capsule shape for $P$. vulgaris would include pyriform (pear-shaped) and rarely globular (Legendre \& Cieslak 2007).

\section{Pinguicula macroceras subsp. nortensis?}

In 1975, Steiger published a casual reference to a new entity he called "Pinguicula macroceras subsp. nortensis", with little more than a comment on habitat and chromosome number ${ }^{1}$. Twelve years later ${ }^{2}$, Rondeau \& Steiger (1997) established the name Pinguicula macroceras subsp. nortensis J. Steiger \& J.H. Rondeau for those plants that occur near the border of California (N Del Norte, W Siskiyou counties) and Oregon (S Curry, S Josephine counties) within $80 \mathrm{~km}$ of the Pacific Ocean, almost invariably on serpentinic outcrops or soils (Rondeau 1995). This region marks the southwestern-most extent of Pinguicula in the USA. Pinguicula

\footnotetext{
${ }^{1}$ Steiger (1975) gives this as $2 n=32$, but later revised this to $2 n=64$ (Rondeau \& Steiger 1997), which is the same ploidy level as all the other Pinguicula discussed in this paper.

2This name's saga may not be over! In drafting the Lentibulariaceae treatment for the new Flora of California (The Jepson Manual, 2nd Edition), one of the coauthors (BR) was told that the name Pinguicula macroceras subsp. nortensis was not published in a journal of sufficient distribution size to be considered "validly published."
} 
Table 1: Characters used for Pinguicula macroceras and $P$. vulgaris identification.

\begin{tabular}{|c|c|c|c|c|}
\hline & P. vulgaris 1 & P. macroceras s. lat. ${ }^{1}$ & $\begin{array}{l}\text { P. macroceras } \\
\text { subsp. nortensis } 2\end{array}$ & Castle Crags area site 3 \\
\hline Spur & (1)3-6(10) mm & (1)6-9(11) mm & $6-11 \mathrm{~mm}$ & (1.5)6-8(9) mm \\
\hline Corolla & (9) $15-22(29) \mathrm{mm}$ & $(12) 18-27(30) \mathrm{mm}$ & $13-21 \mathrm{~mm}$ & (17)24-28 mm \\
\hline $\begin{array}{l}\text { Lower } \\
\text { corolla } \\
\text { lobes }\end{array}$ & $\begin{array}{l}\text { Oblong; not } \\
\text { touching or over- } \\
\text { lapping }\end{array}$ & $\begin{array}{l}\text { Subobovate-oblong, } \\
\text { entire; touching or } \\
\text { overlapping }\end{array}$ & $\begin{array}{l}\text { Oblong, entire; } \\
\text { not touching or } \\
\text { overlapping }\end{array}$ & $\begin{array}{l}\text { Oblong, entire to } \\
\text { emarginate; not touch- } \\
\text { ing or overlapping }\end{array}$ \\
\hline $\begin{array}{l}\text { Calyx } \\
\text { fusion }\end{array}$ & $1 / 2-2 / 3$ & $1 / 2$ & $1 / 2$ & $(1 / 3) 1 / 2-2 / 3(3 / 4)$ \\
\hline $\begin{array}{l}\text { Calyx } \\
\text { shape }\end{array}$ & $\begin{array}{l}\text { Ovate- } \\
\text { lanceolate }\end{array}$ & Lanceolate & Blunt-tipped & Ovate, blunt-tipped \\
\hline $\begin{array}{l}\text { Capsule } \\
\text { shape }\end{array}$ & $\begin{array}{l}\text { Ovoid; also pyri- } \\
\text { form or globular } 4\end{array}$ & Ovoid & Globular $^{5}$ & Ovate to pyriform \\
\hline \multicolumn{5}{|c|}{$\begin{array}{l}{ }^{1} \text { Unless otherwise indicated, } \\
\text { 2Data in this column from Ron } \\
{ }^{3} \text { Newly reported data. } \\
\text { 4Legendre \& Cieslak (2007). } \\
\text { 5From Rondeau (1995, p19). }\end{array}$} \\
\hline
\end{tabular}

populations occur at widely separated sites in this part of its range. As to be expected, these separated populations have distinct characteristics. It is this kind of distribution that invites disagreement among taxonomists: should the plants in these populations be given separate names, or should they be lumped together into a few, variable species?

The characters separating P. macroceras subsp. nortensis from P. macroceras subsp. macroceras are given in Table 1 . The key differences are the shape of the tips of the calyx lobes, the shape and degree of overlap in the lower corolla lobes, and the flower dimensions. The authors also describe corolla hair differences, although they do not provide illustrations which would be useful in interpreting their comments. The capsule of $P$. macroceras subsp. nortensis is noted as globose (Rondeau 1995).

To illustrate the separation of characteristics of $P$. vulgaris, $P$. macroceras subsp. macroceras, and $P$. macroceras subsp. nortensis, we have plotted character ellipses on Figure 1 . These ellipses use the spur lengths as the vertical major axes, and the corolla lengths as the horizontal major axes. In plotting these ellipses, we used the inner ranges for the value ranges from Table 1. For example, since Casper (1966) indicates the spur length of $P$. vulgaris to be "(1)3-6(10) mm", we used 3-6 mm as the vertical major axis for the $P$. vulgaris ellipse. Notice that the three taxa separate readily on this figure. There is considerable overlap between the two $P$. macroceras taxa, but this is to be expected since the dimensions used for $P$. macroceras subsp. macroceras given by Casper include plants later separated into $P$. macroceras subsp. nortensis.

If one were to include the complete range of observed values in creating character ellipses (i.e., 1-10 $\mathrm{mm}$ for the spur length for P. vulgaris), the situation is far more ambiguous. Figure 2 shows such a set of character ellipses. It is clear from this figure that, when considering outliers, the different populations of plants are not well separated. The different appearances of these two figures are central to the disagreements between taxonomic lumpers and splitters.

The characteristics specified by Rondeau \& Steiger (1997) were selected to indicate how their new subspecies differed from $P$. macroceras subsp. macroceras. However, it is interesting to note that in some ways, $P$. macroceras subsp. nortensis is a population of plants that emulate $P$. vulgaris (mostly differing only in spur length and calyx tip shape, but with similar flower size 


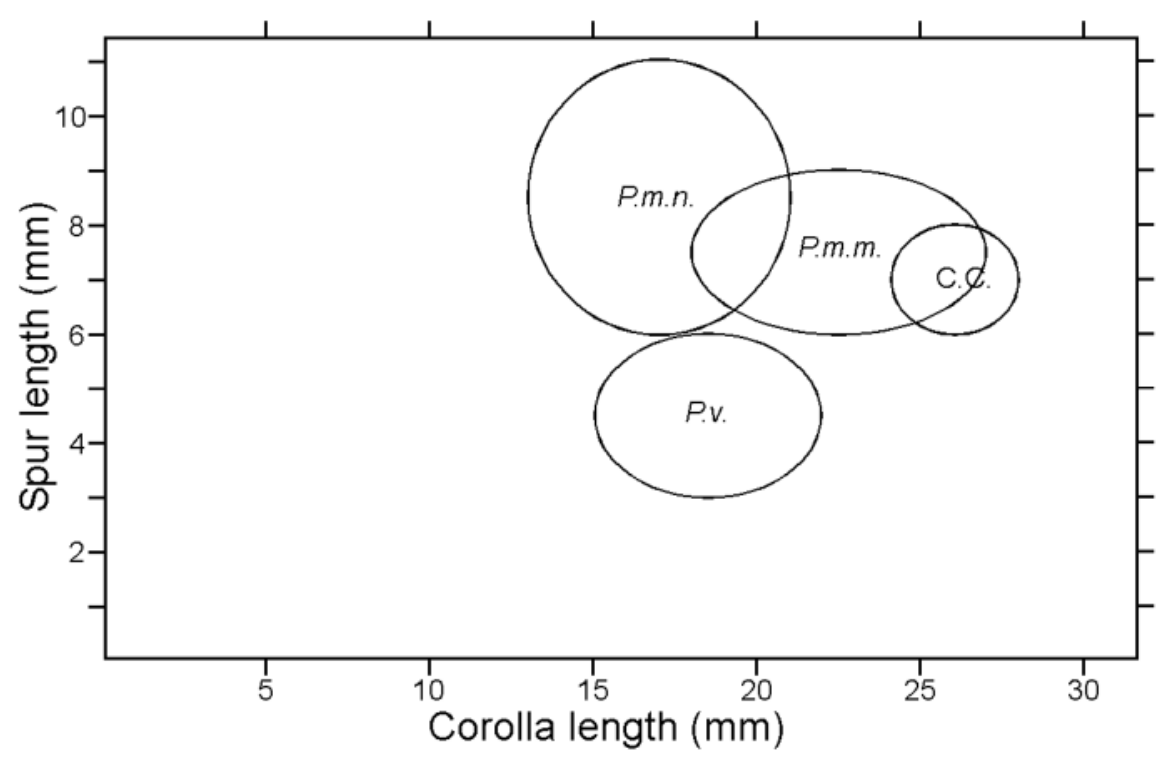

Figure 1: Character ellipses for Pinguicula vulgaris ("P.v."), P. macroceras subsp. macroceras ("P.m.m."), P. macroceras subsp. nortensis ("P.m.n."), and the Californian population from the Castle Crags area ("C.C."). The vertical and horizontal major axes of each ellipse are set by the spur length range, and corolla length range (including spur), respectively. The values used are those for the inner ranges given for each character in Table 1 (i.e., 3-6 $\mathrm{mm}$ for the spur length for $P$. vulgaris).

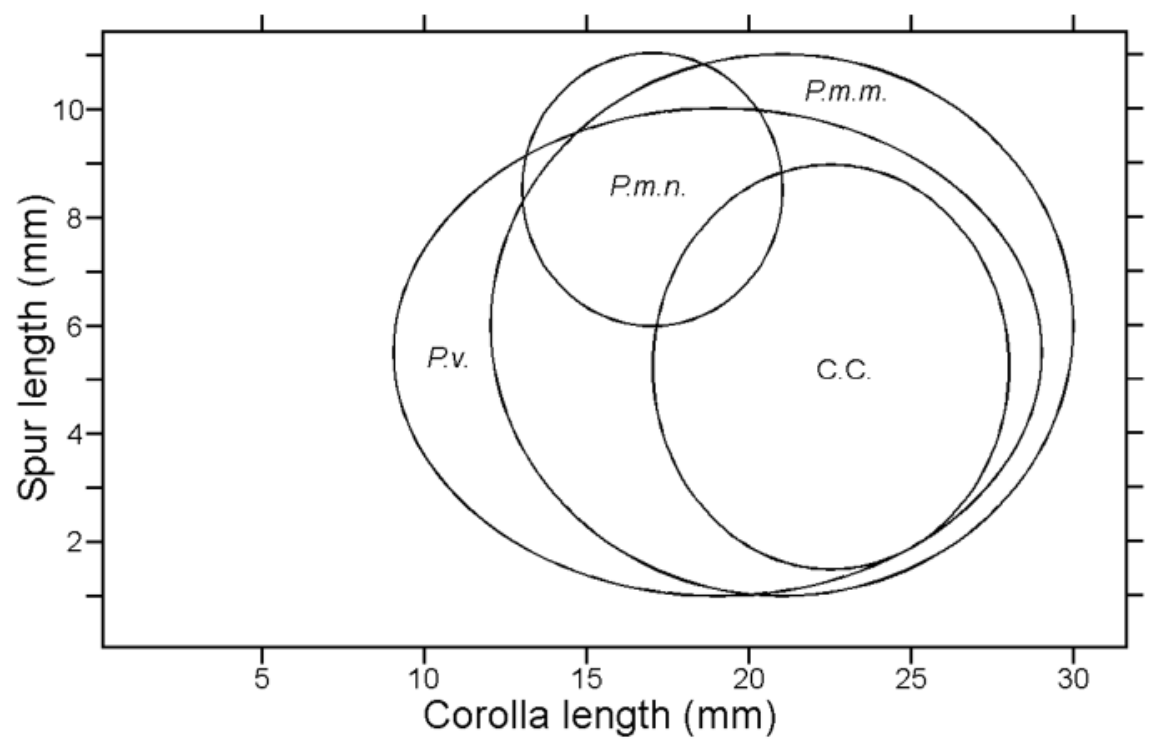

Figure 2: Character ellipses as in Figure 1, but for the entire range of character values supplied by the authors in Table 1 (i.e., $1-10 \mathrm{~mm}$ for the spur length for $P$. vulgaris). Since Rondeau \& Steiger (1997) did not provide such data, the same character ellipse from Figure 1 is repeated for $P$. macroceras subsp. nortensis). 
and petal shape). Given this, we pose the question: if these plants were displaced far to the east, would they be considered worthy of separation from P. vulgaris at any taxonomic level?

\section{Site Comments: California}

Led by Hawkeye Rondeau in 2002, one of us (AY) visited a site in south-central Siskiyou County not far from the Castle Crags Wilderness. Rondeau had heard rumors from a retired Forest Service employee of a Pinguicula population in this area, and had previously made a number of unsuccessful attempts to find them. Verifying the presence Pinguicula at this site would have been remarkable, since it would be a site $100 \mathrm{~km}$ southeast of any known Pinguicula sites (Rondeau, pers. comm. 2007). Although the 2002 trip was unsuccessful, two of us (AY, GM) returned in September 2005 and successfully found the population of plants growing on steep rock slopes. This precipitated a September 2006 trip by all three authors (and Elizabeth Salvia) to follow up on the observations.

The area is remarkable for many botanical and geological reasons. Marking the origin of a now-melted glacier, the region is rich in ericaceous species. Before our visit, the area was also known to house carnivorous Darlingtonia californica Torr. and Drosera rotundifolia L. During our 2006 trip, we also detected Utricularia macrorhiza LeConte in one of the many small lakes in the area; this latter plant was a new addition to the plants known in the area. In July 2007, the four of us returned to the area. With collection permits in hand, we were able to document both $U$. macrorhiza and $U$. minor L. in two lakes. Within a distance of a few kilometers, this area has five different carnivorous species from four genera, making it unexcelled in carnivorous plant diversity in the state.

The Pinguicula plants were in flower during the 2007 trip and easily rediscovered on serpentinic strata. We were astonished by the nature of the white patch on the lower corolla lipit was much larger and clearer white than we had observed on other plants (see Figures 3, 4). Although striking, this is not considered a feature of taxonomic importance. Since the plants occur on privately owned land we were unable to collect plant material, but we did document the plants photographically and measure their floral characters.

We measured the following characters for 34 flowers: corolla length (including spur), spur length, and degree of calyx lobe fusion. Following the steps of Casper (1962), who apparently used the half-height of his distributions to define parameter ranges, we determined spur length and corolla length ranges (Table 1). Corolla lengths were measured by resting the flower on a ruler, so the effects of petals hanging downwards were addressed. The minimum spur $(1.5 \mathrm{~mm})$ and flower $(17 \mathrm{~mm})$ lengths are from three additional flowers that were clearly distorted and malformed. Character ellipses for the plants are plotted in Figures 1 and 2. The results suggest that this population of plants seems more allied with P. macroceras subsp. macroceras (at least on the basis of floral dimensions). However, the corolla shapes were variable and not diagnostic of one taxon or another. Alas, there are no easy answers here!

We observed with interest that nearly all the flowers had long spurs with minutely bifid tips (see Figure 5,6). The lower lateral corolla lips were oblong and spreading, although the lower central lip was oblong-obovate and often clearly emarginate (see Figures 4, 5).

The calyx lobes were predominately (73\%) fused $1 / 2$ their lengths, although approximately $1 / 4(21 \%)$ had calyx lobes fused $2 / 3$ their lengths. Also noteworthy was that the capsules of nearly mature fruit were markedly asymmetric, and conical to pear-shaped (see Figure 7, left).

\section{Site Comments: Oregon}

In July 2006, one of us (BR) visited a Pinguicula site in Wallowa County, in eastern Oregon. A number of populations of Pinguicula occur in this area, but as there was little discretionary time to reach them, all the time was focused on one population of several hundred plants found 


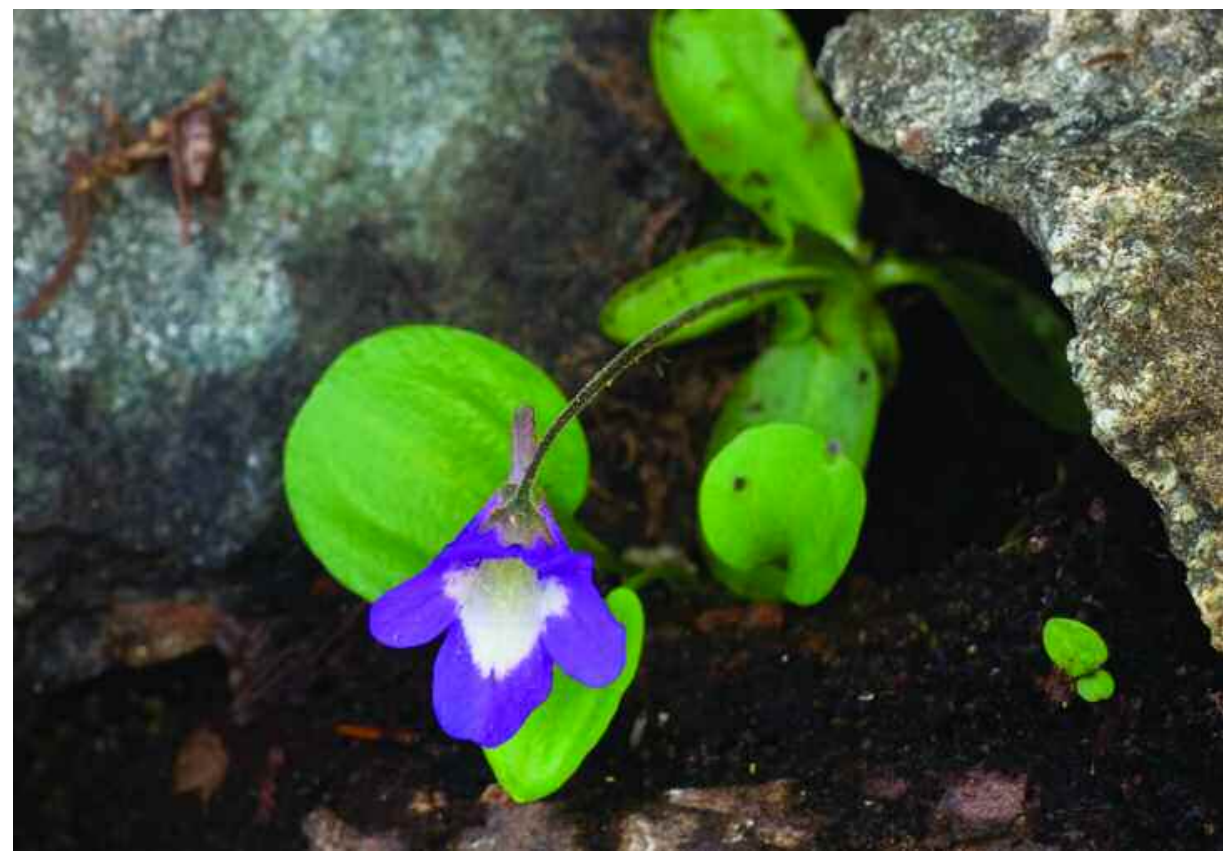

Figure 3: A plant from the Castle Crags, California area. Note how the lower corolla lobes tend to overlap, suggesting the identification as $P$. macroceras subsp. macroceras. Photograph by Barry Rice.

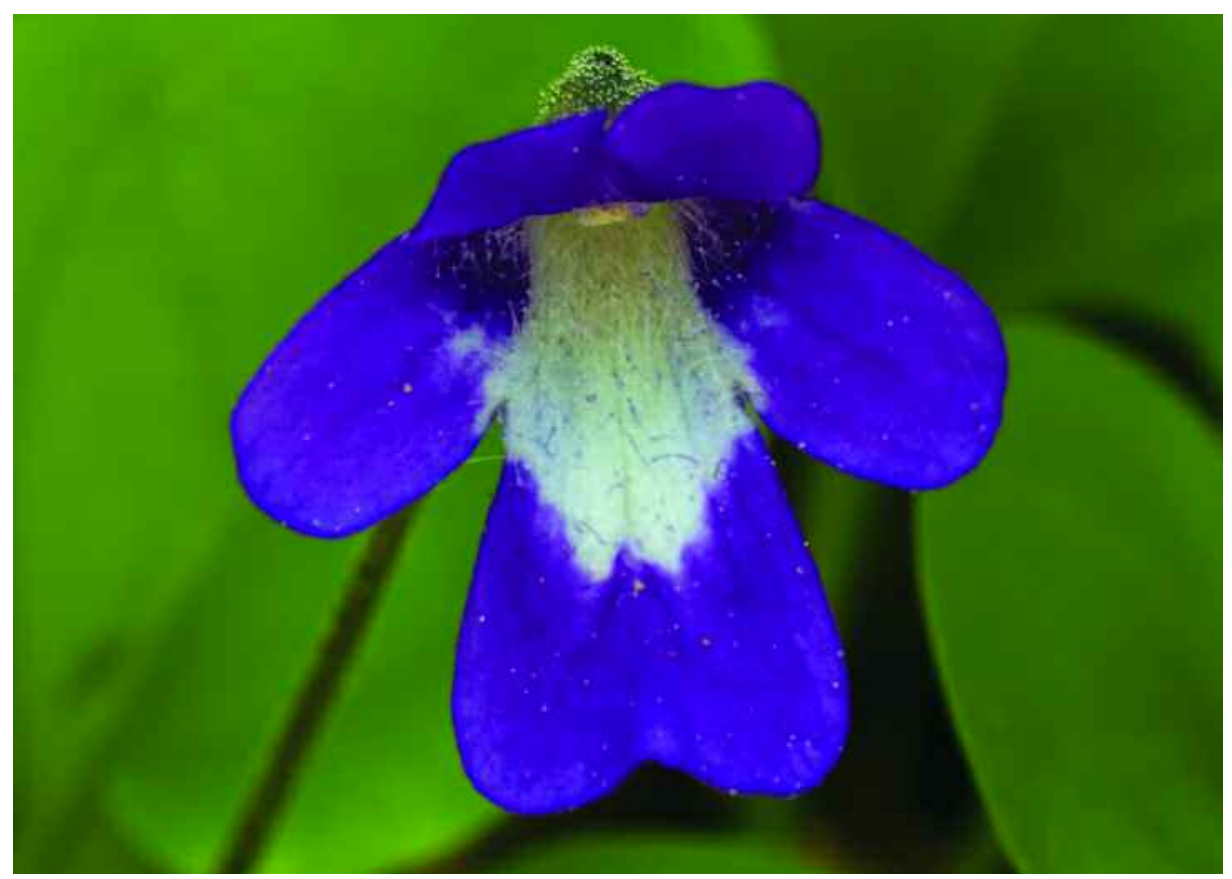

Figure 4: A flower from the Castle Crags, California area. Note how the lower corolla lobes are spreading in this specimen, and the emarginate central-lower lip. Photograph by Barry Rice. 


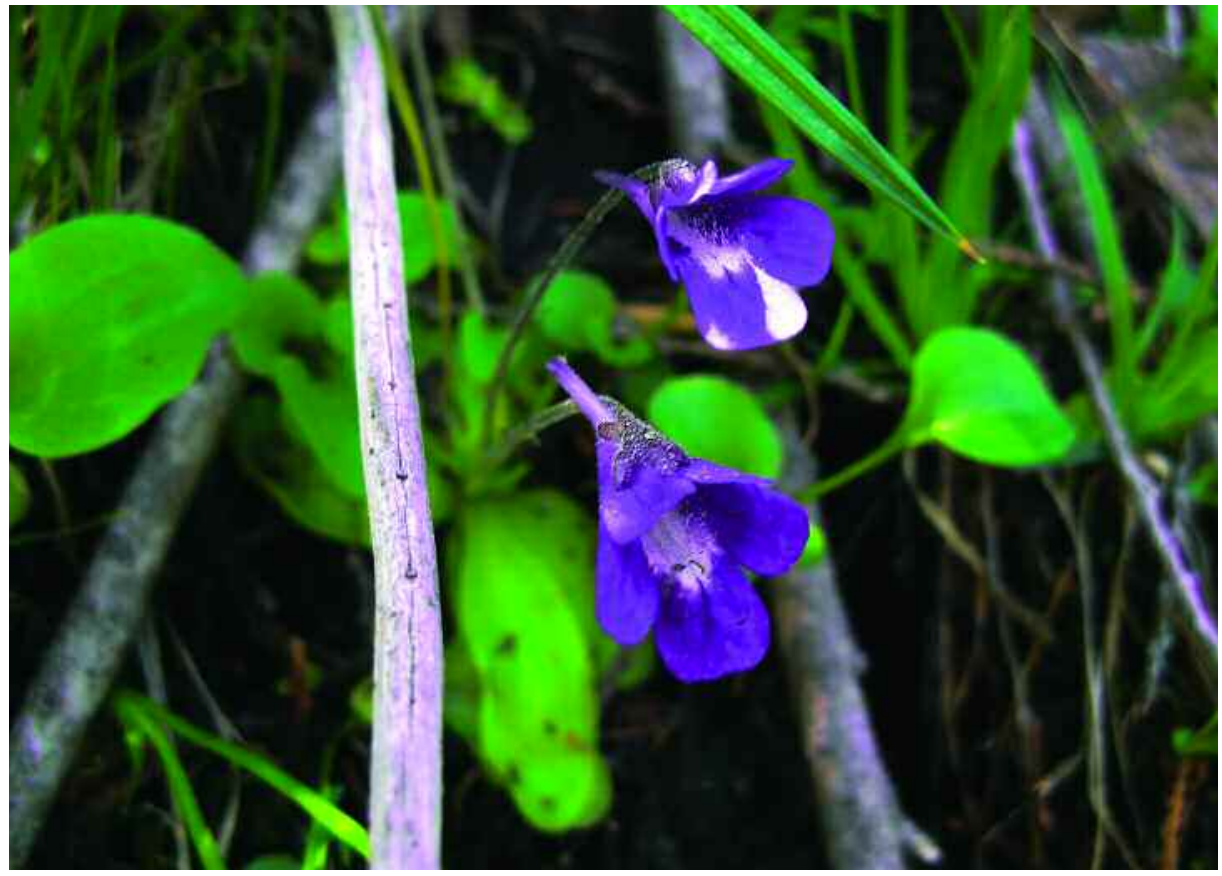

Figure 5: Two flowers from the Castle Crags, California area. Notice the nearly overlapping lower corolla lobes and the minutely bifid spurs. Photograph by Arthur Yin.

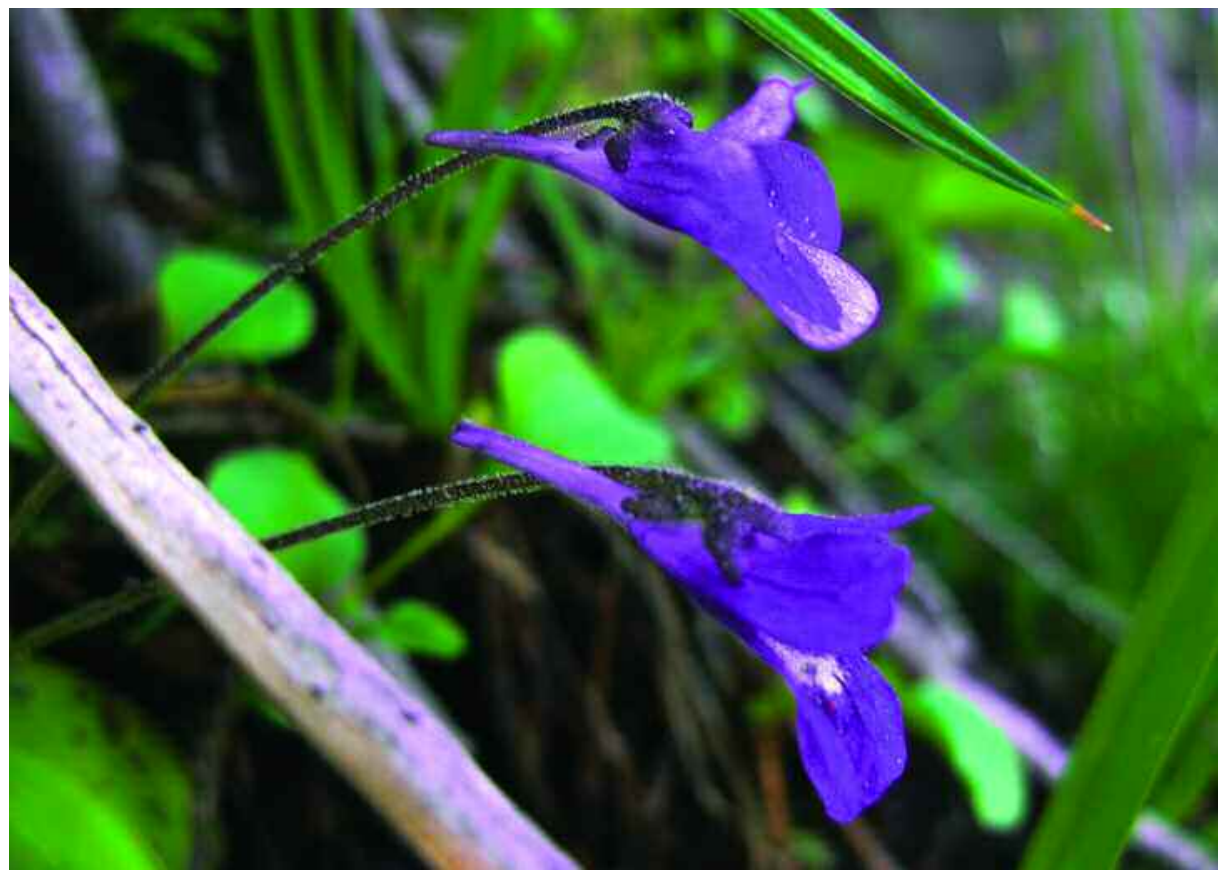

Figure 6: The same two flowers shown in Figure 5, in profile. Notice the long spurs. Photograph by Arthur Yin. 
growing in the spray of a small waterfall coursing down the spectacular Wallowa Mountains. As is typical for western USA Pinguicula, these plants were living either in cracks on the bare wet (in this case non-serpentinic) rock, or in small pockets of moist soil that had accumulated near the flowing water.

Conveniently, the plants were in flower at the time of the visit, and a number of observations and measurements were made. Most remarkably, the plants at this site all had extremely small rosettes, approximately $3-4.5 \mathrm{~cm}$ across at maturity. Some of the plants were in fruit, and had developed globular, nearly spherical fruit with little significant asymmetry (see Figure 7 , middle).

The lower calyx lobes were fused approximately $1 / 2$ of their lengths and were blunt-tipped. Based upon a small sample of only seven flowers, the spur lengths were 5.5-6.3 mm (avg. 5.8 $\mathrm{mm}$ ), and total corolla lengths (including spur) were 16.3-19.0 mm (avg. $17.9 \mathrm{~mm}$ ). These measurements were obtained by photographing the flowers with rulers in the field of view. The spurs were cylindrical and blunt-tipped (two spurs were minutely emarginate, as in the Californian plants described earlier). The lower corolla lobes were entire, spreading, and at most barely touching. In shape they were somewhere between obovate and oblong. The white spot on the lower lip was relatively small (see Front Cover).

Plants in this geographic range were included in the list of specimens examined by Casper (1962), and treated by him as P. macroceras. How should the plants in this pocket population be classified? It is unclear as too few plants were measured to make a statistically significant statement, or to create reliable character ellipses as in Figures 1 and 2. The nature of the corolla lobes is consistent with just about any of the three entities we have discussed; we will allow future workers to puzzle this issue more fully.

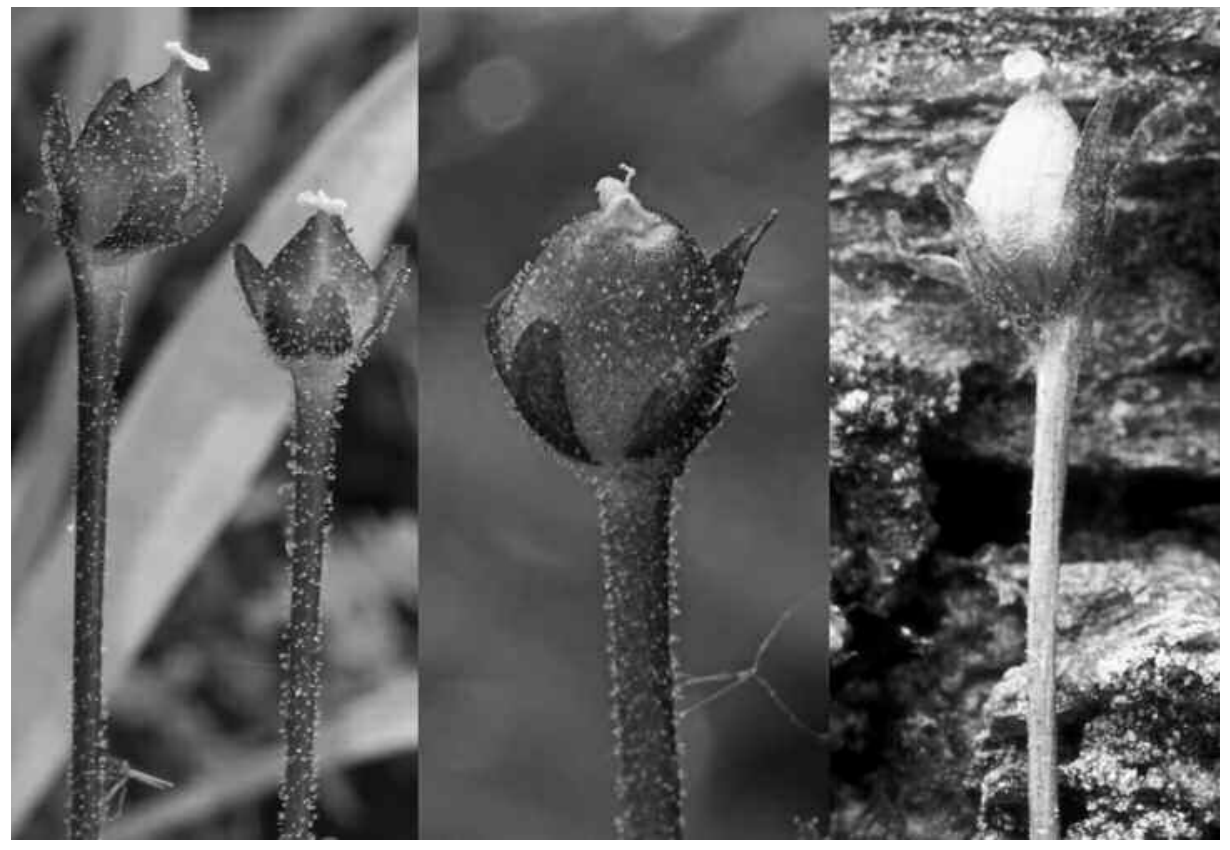

Figure 7: Pinguicula infructescences from sites discussed in the text: California (left), Oregon (middle), Montana (right). Images are not all at the same scale. Photographs by Barry Rice. 
In the fall of 2006, one of us (BR) had the opportunity to explore parts of western Montana. During this trip attempts were made to see Pinguicula populations in Glacier National Park, but only one site was reached. This site was an alpine roadside location at $1750 \mathrm{~m}$ a.s.l. where water permanently trickled over non-serpentinic rock slabs. The Pinguicula were entering dormancy, and it was so late in the season that the fruit had mostly all dehisced. However, a few useful observations were possible.

First, the mature capsules were elongated with obtuse tips, and asymmetrically mounted (see Figure 7, right). Second, all the calyx lobes were deeply divided to a depth of about 1/2 their total length, and were sharply pointed. (Since these observations were not made at anthesis, it is possible they might have changed as the capsules matured.) Finally, these plants were large; comparable in size to those that are typically seen along the California-Oregon border.

Plants from this range were included in the list of specimens examined by Casper (1962), but it would be interesting to review these specimens in flower to learn more about their affinities. However, from the observations in hand, it would seem that these plants would be assigned to $P$. macroceras subsp. macroceras.

Montana, incidentally, has a number of other remarkable and as yet underappreciated surprises for carnivorous plant enthusiasts, such as a few highly disjunct populations of Drosera linearis Goldie. However, to see such plants naturalists must be equipped with a strong back, a good set of legs, and a willingness to hike in lands with large populations of black bears and grizzly bears!

\section{Concluding Notes}

In the western states of the USA, Pinguicula occur in isolated sites. Separated by distances far greater than those traversed by pollinators, these plants are likely not in genetic communication and have developed into populations that have differences as well as similarities. How these are to be interpreted is possibly as much a matter of philosophy as botany, and we encourage discussion on the topic. This is clearly a complicated matter, and our exposure to the species discussed here (and related species in Pinguicula sect. Pinguicula) is as yet too limited to give us confidence to enter this difficult matter any further than we already have.

For the horticulturist seeking the certain identification of plants in their collections, madness surely awaits: a single cultivated plant will probably be impossible to identify with security. The only way that a horticulturist can be sure of his or her plants' identities is to religiously track their provenance information.

Science may never reach consensus on the status of these plants. But does that matter? Overall, we do not think so. Our lack of understanding does not detract from their wonders. So let us do the right thing and protect them from damage, so that our descendents can have the same pleasure in scratching their heads in confusion and frustration.

Acknowledgements: Arthur Yin and Gina Morimoto wish to thank Hawkeye Rondeau for his guidance to find and research this wonderful site throughout these past years. Barry Rice wishes to thank his wife Elizabeth Salvia for her supporting fieldwork, Julie K. Nelson (US Forest Service) for speedy processing of California collection permits, the owners of the California site for permitting our continuing research on their property, Peter Lesica (University of Montana) and Hawkeye Rondeau for site suggestions in Montana, and Rob Taylor (The Nature Conservancy) for site suggestions in eastern Oregon. The authors wish to thank Juerg Steiger for his helpful suggestions as a referee for this paper. No permits were required to visit the public and unposted private locations described in this paper; Utricularia collections were conducted under permit \#16080 granted by the US Forest Service (Shasta-Trinity National Forest). Because of the sensitivity of these sites, location information will not be discussed with the public. Both 
before and after leaving the California site, we sprayed our boots with a 10 percent bleach solution. The area is infected with the fungal pathogen Phytophthora lateralis Tucker \& Milbrath. This pathogen causes Port Orford cedar root disease in Cupressus lawsoniana A. Murray, a tree frequently associated with Darlingtonia habitats and which may have an important role to play in sustaining the conditions suitable for Darlingtonia. We encourage all visitors to Darlingtonia habitat to keep their boots clean to avoid spreading this pathogen.

\section{References}

Casper, S.J. 1962. On Pinguicula macroceras Link in North America. Rhodora. 64: 212-221.

Casper, S.J. 1966. Monographie der Gattung Pinguicula L. Stuttgart: Bibliotheca Botanica. Heft 127/128: 171-179, Figure 45.

Legendre, L. and Cieslak, T. 2007. Pinguicula vulgaris L. in the Champagne state of France: life in an alkaline bog. Carniv. Pl. Newslett. 36: 104-113.

Rondeau, J.H. 1995. Carnivorous Plants of the West, Vol. II: California, Oregon and Washington. Privately published by author. ix $+82 \mathrm{p}, \mathrm{p} 15-24$.

Rondeau, J.H. and Steiger, J.F. 1997. Pinguicula macroceras subsp. nortensis, a new subspecies of Pinguicula (Lentibulariaceae) from the California-Oregon border. International Pinguicula Study Group Newsletter 8: 3-8.

Schnell, D.E. 2002. Carnivorous plants of the United States and Canada. (2nd Edition) Timber Press, Portland, 468p, p296-308.

Schlauer, J. 2002. World Carnivorous Plant List-Nomenclatural Synopsis of Carnivorous Phanerogamous Plants, http://www.omnisterra.com/bot/cp_home.cgi, accessed July 2007.

Steiger, J.F. 1975. The Pinguicula species of the temperate growth type and their cultivation. Carniv. Pl. Newslett. 4: 8-18.

Steiger, J.F. 1978. Standardized photography of Pinguicula blossoms. Carniv. Pl. Newslett. 7: 43-50.

Steiger, J.F. 1982. Pinguicula macroceras photographs. Carniv. Pl. Newslett. 11: 29, 52.

Wells, J.R., Case, F.W., and Mellichamp, T.L. 1999. Wildflowers of the Western Great Lakes Region. Wayne State University Press, Michigan, 304p, p253.

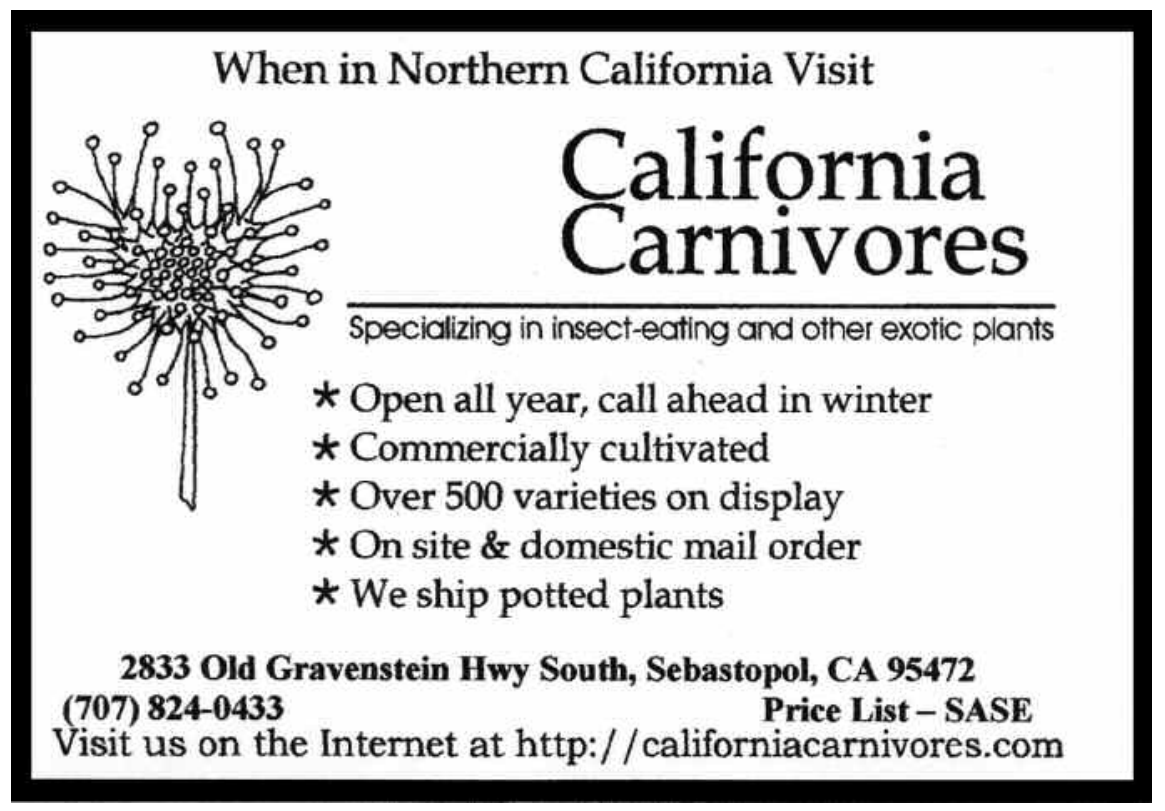




\section{CARNIVOROUS PLANT NEWSLETTER}

Journal of the International Carnivorous Plant Society 


\section{CARNIVOROUS}

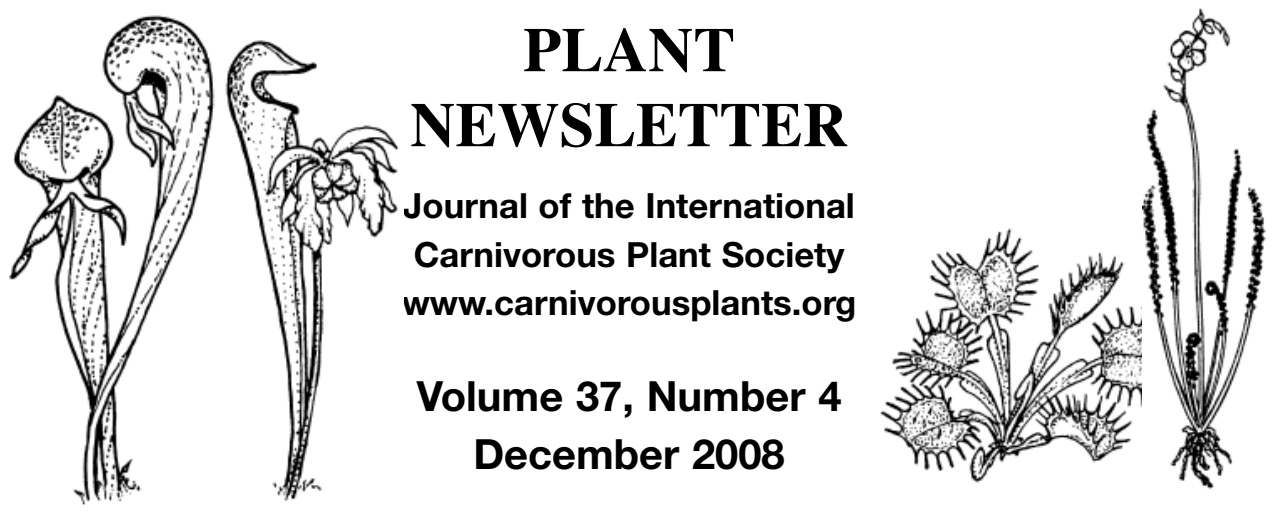

Front cover: Pinguicula macroceras from eastern Oregon. Article on page 100. Photograph by Barry Rice.

Back Cover: The new cultivar Utricularia 'Nüdlinger Flair'. Article on page 110. Photograph by Thomas Carow.

Carnivorous Plant Newsletter is dedicated to spreading knowledge and news related to carnivorous plants. Reader contributions are essential for this mission to be successful. Do not hesitate to contact the editors with information about your plants, conservation projects, field trips, or noteworthy events. Contributors should review the "Instructions to Authors" printed in the March issue of each year. Advertisers should contact the editors.Views expressed in this publication are those of the authors, not the editorial staff.

All correspondence regarding dues, address changes and missing issues should be sent to the Membership Coordinator at the ICPS. Do not send such correspondence to the editors. Checks for subscriptions should be made to the ICPS in US funds. Dues for 2008 are $\$ 25$.
ICPS, Inc.
PMB 322
1564-A Fitzgerald Drive
Pinole, CA 94564-2229, USA
icps@carnivorousplants.org

President Doug Darnowski, doug@carnivorousplants.org

Vice President Cindy Slezak, cindy@carnivorousplants.org

Secretary, Seed Bank John Brittnacher, john@carnivorousplants.org, seed bank listed in this issue.

Treasurer

Board Member

Richard Myers, richard@carnivorousplants.org

Board Member

Chris Teichreb, chris@carnivorousplants.org

Bob Ziemer, bob@carnivorousplants.org

Editors:

Barry A. Rice, P.O. Box 72741, Davis, CA 95617, USA, barry@ carnivorousplants.org

Jan Schlauer, Zwischenstr. 11, D-60594 Frankfurt, Germany, jan@carnivorousplants.org

Graphic Design: Suzanne Hedderly, suzanne@carnivorousplants.org

Date of effective publication of the September 2008 issue of Carnivorous Plant Newsletter: 29 August 2008.

The ICPS is the International Cultivar Registration Authority (ICRA) for cultivated carnivorous plants according to The International Code For The Nomenclature of Cultivated Plants. Send relevant correspondence to the ICPS, Inc.

PUBLISHER: ICPS, Inc., Pinole, California. Published quarterly with one volume annually. Graphic Production: Suzanne Hedderly, 1500 West Laburnum Avenue, Richmond, VA. Printer: Kandid Litho. Logo and masthead art: Paul Milauskas. Dues: \$25.00 annually. ㅇ 2008 Carnivorous Plant Newsletter. All rights reserved. ISSN \#0190-9215. 